\title{
Identifikasi Kedalaman Perairan (Batimetri) Terhadap Nilai Kedalaman Data Satelit di Perairan Batu Ampar, Batam
}

\author{
Muhammad Zainuddin Lubis ${ }^{1 *}$, Widya Rika Puspita ${ }^{2}$, B. Budiana ${ }^{2}$, Jhon \\ Hericson Purba ${ }^{2}$, Rahman Hakim ${ }^{3}$ \\ ${ }^{1}$ Politeknik Negeri Batam, Jurusan Teknik Informatika, Batam \\ ${ }^{2}$ Politeknik Negeri Batam, Jurusan Teknik Elektro, Batam \\ ${ }^{3}$ Politeknik Negeri Batam, Jurusan Teknik Mesin, Batam \\ "E-mail: zainuddinlubis@polibatam.ac.id
}

\begin{abstract}
Abstrak
Kedalaman (batimetri) laut memberikan berbagai informasi penting mengenai suatu area laut. Selain untuk navigasi pelayaran, kedalaman dan lain sebagainya, dengan mengetahui kedalaman sebenarnya pada sebuah area laut tersebut dapat dibuat sebuah sistem yang bisa mengidentifikasi kedalaman perairan pada tersebut. Wilayah Kota Batam terdiri dari Pulau Batam, Pulau Rempang dan Pulau Galang dan pulau-pulau kecil lainnya di kawasan Selat Singapura dan Selat Malaka. Pasang surut merupakan fluktuasi muka air laut yang terjadi akibat gaya tarik benda-benda di langit, terutama pada matahari dan juga bulan terhadap massa air pada laut bumi. Kemudian dilakukan pengolahan data pasang surut menggunakan metode perhitungan kuadrat terkecil (least square) untuk mengetahui nilai konstanta harmonik. Hasil dari pengolahan data tersebut menghasilkan nilai formzahl standart error. Berdasarkan pengukuran langsung yang dilakukan di perairan Batu Ampar, Batam mendapatkan nilai kedalaman -4,15 meter sampai -13,00 meter di bawah permukaan laut dengan rata-rata kedalaman yaitu $-7,24 \pm-2,03 \mathrm{~m}$ dibawah permukaan laut. Hasil pengukuran pasut selama 15 hari (11-25 September 2018), diperoleh nilai formzahl sebesar 0,6660815047 yang menandakan bahwa pelabuhan Batu Ampar memiliki tipe pasang surut campuran condong ke harian ganda. Nilai-nilai elevasi water level dari hasil perhitungan pasut adalah: $\mathrm{HHWL}=2,3 \mathrm{~m} ; \mathrm{MHWL}=2 \mathrm{~m} ; \mathrm{MSL}=1,65 \mathrm{~m} ; \mathrm{MLWL}=-0,25 \mathrm{~m} ; \mathrm{LLWL}=-0,6 \mathrm{~m}$. Uji regresi dan standard error didapatkan: Standar Error $=6.593932009$ dan nilai regresi $=0,0057044$.
\end{abstract}

Kata kunci: Batimetri, pasang surut, least square, formzahl

\begin{abstract}
The depth (bathymetry) of the sea provides a variety of important information about the sea area. In addition to navigation, depth, and so on, by knowing the actual depth in an area of the sea, a system is made to identify the depth of the waters at that sea level. Batam City area consists of Batam Island, Rempang Island, and Galang Island and other small islands in the Singapore Strait and Malacca Strait. Tides are fluctuations in sea levels due to the attraction of objects in the sky, especially the sun and the moon on the water masses of the Earth's seas. Then, tidal data processing is carried using the least square calculation method to determine the harmonic constants' value. The results of the data processing produce standard error formzahl values. Based on direct measurements carried out in Batu Am-par waters, Batam obtained a depth value of -4.15 to -13.00 meters below sea level with an average depth of $-7.24 \pm-2.03 \mathrm{~m}$ below sea level. The results of tidal measurements for 15 days (11-25 September 2018), obtained a formzahl value of 0.6660815047 which indicates that the Batu Ampar port has a mixed tidal type that tends to double daily. The values of the water level from the tide calculation are: $H H W L=2.3 \mathrm{~m} ; M H W L=2 \mathrm{~m} ; M S L=1.65 \mathrm{~m} ; M L W L=-0.25 \mathrm{~m} ; L L W L=-0.6 \mathrm{~m}$. Regression test and standard error obtained: Standard Error $=6.593932009$ and regression value $=0.0057044$.
\end{abstract}

Keywords: Bathymetry, tides, least square, formzahl 


\section{Pendahuluan}

Perairan Batu Ampar, Batam, Kepulauan Riau merupakan daerah perairan yang padat akan lalu lintas kapal angkut dan kapal penumpang, dikarenakan lokasi ini merupakan lokasi pelabuhan angkut muat barang secara Nasional. Pengukuran nilai kedalaman suatu perairan merupakan hal penting dalam sebuah peraira yang berdekatan dengan pelabuhan yang terkenal aktif dalam transportasi logistik berskala nasional. Di Kecamatan Batu Ampar ini terdapat pelabuhan Batu Ampar yang memiliki lalu lintas tertinggi baik untuk kegiatan ekspor maupun kegiatan impor. Hal ini dikarenakan pelabuhan Batu Ampar merupakan pelabuhan barang terbesar di Kota Batam. Oleh karena itu, diperlukan pemetaan batimetri dan kondisi topografi di perairan pelabuhan Batu Ampar dengan memanfaatkan data batimetri dan data satelit pasang surut di Batu Ampar [1-2].

Peta batimetri menggambarkan kedalaman perairan yang disajikan dengan menggunakan garis kontur kedalaman perairan. Garis kontur adalah garis pada peta yang mewakili garis imajiner yang sesuai pada permukaan tanah atau dasar laut yang memiliki ketinggian atau kedalaman perairan yang sama. Ilustrasi nilai kedalaman dapat dilihat pada Gambar 1.

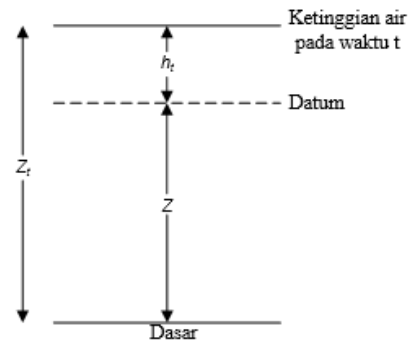

Gambar 1. Ilustrasi Kedalaman [2]

Pemetaan kedalaman suatu perairan sangat tidak terlepas dari pengukuran dan nilai pasang surut laut. Pasang surut merupakan fenomena perubahan elevasi permukaan air laut secara berkala yang dipengaruhi oleh kombinasi gaya gravitasi dan gaya tarik-menarik dari bendabenda astronomi terutama oleh matahari, bulan, dan bumi [3]. Pasang surut air laut memiliki sifat yang dinamis dan di setiap wilayah memiliki karakteristik pasang surut yang berbeda-beda. Tipe pasang surut ini dapat diklasifikasikan berdasarkan perbandingan antara jumlah amplitudo konstanta harmonik utama harian tunggal $\mathrm{K} 1$ dan $\mathrm{O} 1$, dengan jumlah amplitudo konstanta harmonik harian ganda M2 dan S2. Perbandingan ini sering disebut Formzahl [4].

Tujuan dari penelitian ini adalah membandingkan nilai kedalaman perairan di Pelabuhan Batu Ampar dengan data satelit, dengan memanfaatkan pasang surut sebagai koreksi. Koreksi dilakukan dengan mencari nilai standard error dan nilai regresi linear. Perhitungan nilai standard error dan regresi linear perlu dilakukan untuk menguji ketelitian dan validasi data. Tingkat validasi data kedalaman perairan dianalisis dengan menggunakan analisa regresi linear. Analisa regresi dilakukan untuk mengetahui seberapa besar akurasi data batimetri kedalaman perairan.

Konstanta yang diperoleh dalam sebuah harmonik pasang surut memiliki sebanyak dua parameter yang dinyatakan sebuah konstanta, diantaranya, yaitu nilai amplitudo dari beberapa komponen pasang surut, serta keterlambatan phasa dari pasang sebenarnya dalam sebuah pasang surut yang setimbang. Hal ini disebutkan bahwa konstanta harmonik yang diperoleh ini akan digunakan untuk mendapatkan peramalan kondisi pasang surut di perairan tersebut, dalam kurun waktu yang diinginkan [5].

\section{Metode Penelitian}

\section{A. Waktu dan Lokasi Penelitian}

Lokasi kajian ini adalah daerah perairan Pelabuhan Batu Ampar, Batam, Kepulauan Riau, yang secara geografis terletak pada koordinat 000'0.038" LU dan 100030'43.876" BT. Lokasi tersebut dapat dilihat pada Gambar 2.

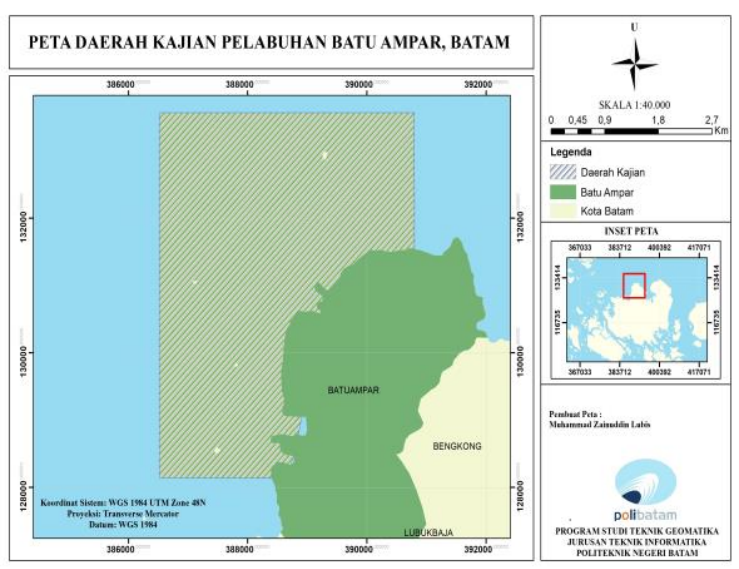

Gambar 2. Lokasi Penelitian 


\section{B. Alat dan Bahan Penelitian}

Adapun alat dan bahan yang digunakan dalam penelitian ini adalah :

Alat

1. PC (Personal Computer)

2. Aplikasi (Surfer 17.1, Arc Map 10.3, Ms.Word, Ms.Excel, Ms.Visio) Bahan

1. Data Pasut Batu Ampar 11-25 September 2018

2. Data Batimetri.xls

3. Data raster GEBCO

\section{Desain Penelitian}

Penelitian ini memiliki desain yang secara garis besar merupakan tahapan dari penelitian yang dapat dilihat dalam diagram alir pada Gambar 3 .

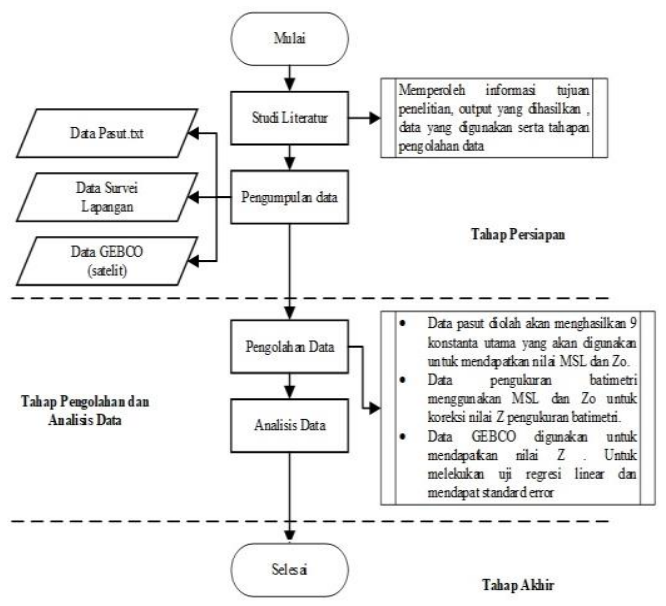

Gambar 3. Desain Penelitian

\section{Tahapan Penelitian}

Tahapan penelitian ini yaitu melakukan pengunduhan data yang diperlukan seperti data pengukuran survei lapangan, data satelit dan data pasut. Data pasut di unduh pada tanggal 25 April 2020

di http://tides.big.go.id/pasut/index.html (tampilan website tersebut dapat dilihat pada Gambar 4) dalam rentang waktu pengukuran pasut yaitu 1125 September 2018. Data tersebut digunakan untuk melakukan pengolahan data pasut. Pengolahan pasut menggunakan Ms.Excel dengan menggunakan metode perhitungan kuadrat terkecil (least square) untuk mengetahui nilai konstanta harmonik [6-7].

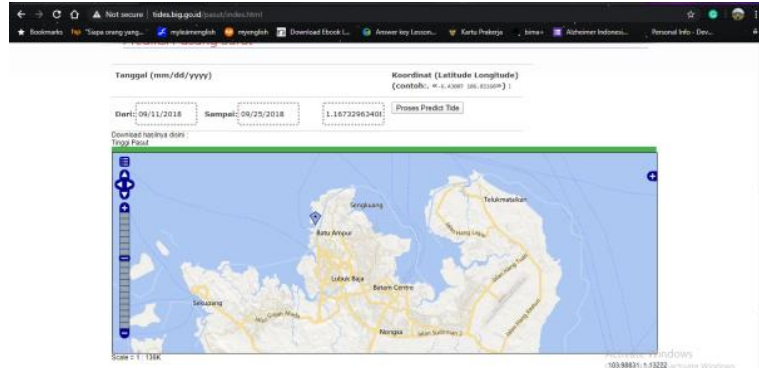

Gambar 4. Tampilan website BIG

Untuk melakukan koreksi posisi dan uji akurasi data yang digunakan adalah data pemeruman menggunakan MBES (Multibeam Echosounder) yang dilakukan pada Tahun 2018 yang dilakukan pengukuran secara langsung, yang merupakan data pengukuran survei lapngan yang sudah terkoreksi dengan Mean Sea level (MSL). Data tersebut digunakan untuk melakukan koreksi posisi di ArcMap dan membuat kontur pada data tersebut (Gambar 5).

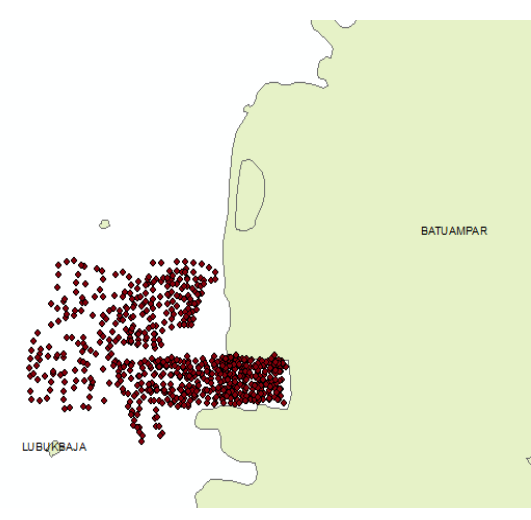

Gambar 5. Uji koreksi posisi data pengukuran batimetri

Selain itu, penelitian ini juga menggunakan data satelit berupa data batimetri yang di download pada tanggal 25 April 2020 di website https://download.gebco.net/, serta memiliki waktu perekaman data pada April 2019, dengan lokasi yang berada di perairan Pelabuhan Batu Ampar. Data tersebut diolah di ArcMap untuk membuat kontur data satelit (Gambar 6).

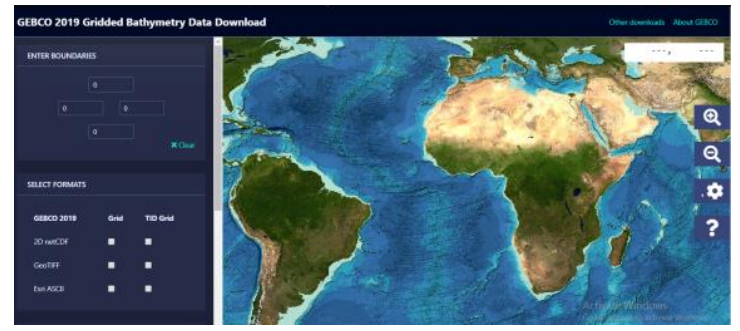

Gambar 6. Tampilan GEBCO 
Dari hasil kedua kontur tersebut dihasilkan nilai Z. Nilai Z pada data pengukuran survei lapangan dikoreksi terlebih dahulu dengan menggunakan persamaan 1 [8].

$$
\mathrm{rt}=\mathrm{TWLt}-(\mathrm{MSL}+\mathrm{Zo}) \quad \ldots
$$

Dimana :

rt : Besarnya reduksi (koreksi) yang diberikan kepada hasil pengukuran kedalaman perairan pada waktu t.

TWLt : Kedudukan permukaan laut sebenarnya (true water level) pada waktu t.

MSL : Muka air laut rata-rata (Mean Sea Level).

Z0 : Kedalaman perairan muka surutan di bawah MSL.

Maka dihasilkan 2 nilai $Z$ yaitu nilai $Z$ terkoreksi pengukuran survei lapangan dan nilai $\mathrm{Z}$ pada data satelit. Kemudian lakukan pengujian regresi linear dan nilai standard error akan memvalidasi hubungan persamaan atau uji keakurasian antar kedua data tersebut.

\section{Hasil dan Pembahasan}

Berdasarkan hasil pengukuran langsung dilapangan, didapatkan bahwa pada wilayah kajian, yaitu kelurahan Batu Merah, Kecamatan Batu Ampar, Kota Batam memiliki kedalaman perairan yang beragam yaitu antara $4,15 \mathrm{~m}-$ $13,00 \mathrm{~m}$ di bawah permukaan laut dengan ratarata kedalaman perairan yaitu 7,24 $\pm 2,03 \mathrm{~m}$ dibawah permukaan laut, berdasarkan nilai ratarata kedalaman perairan, maka wilayah kajian digolongkan kedalam laut dangkal (Gambar 7dan 8).

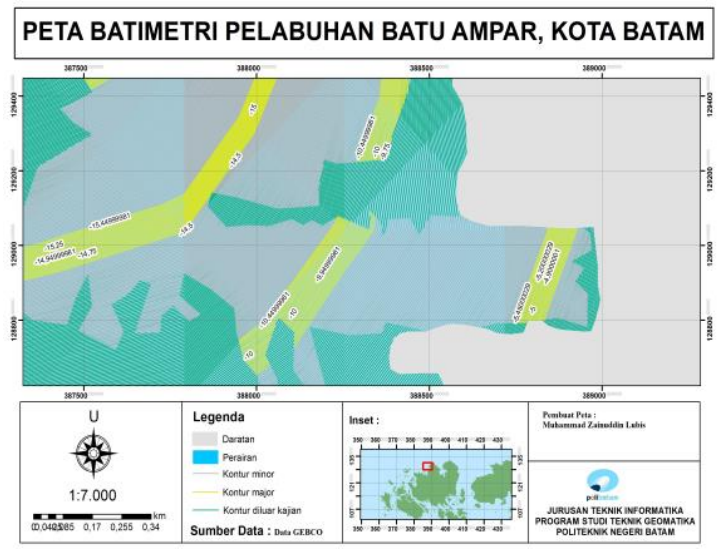

Gambar 7. Peta Batimetri menggunakan data Gebco

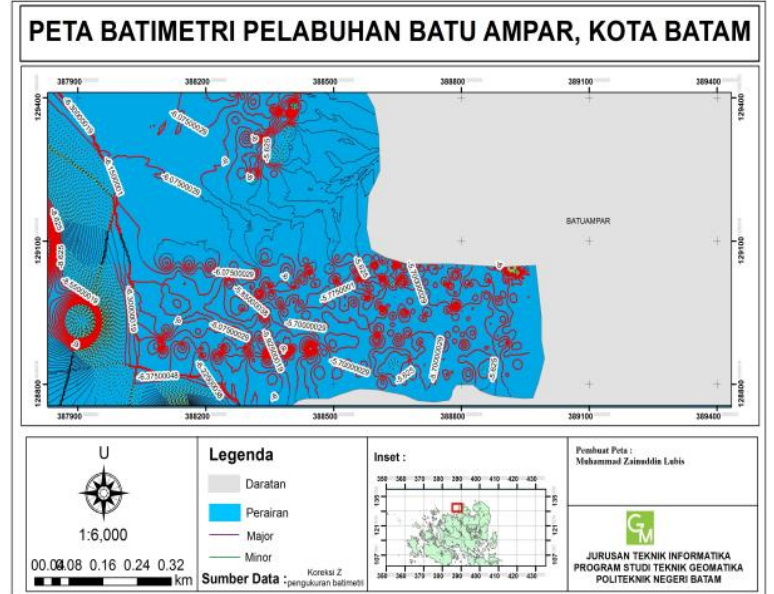

Gambar 8. Peta Batimetri menggunakan data survei lapangan yang telah terkoreksi

Hasil dari pengolahan data terkoreksi dalam nilai kedalaman perairan yaitu pada tampilan 3 dimensi permukaan dasar perairan Batu ampar hasil dari pengukuran (data primer). Pada gambar diatas ditampilkan berdasarkan 5 kelas, dimana pada kelas tersebut kedalaman perairan terkecil yaitu $-4,58$ meter, dan kedalaman perairan paling besar yaitu $-12,96$ meter. Dari gambar diatas, bagian paling dangkal diwarnai dengan warna hijau yaitu berada pada bagian dekat dari bibir pantai, kemudian akan semakin dalam seiring menjauh dari bibir pantai, yang ditandai dengan warna merah (Gambar 9)

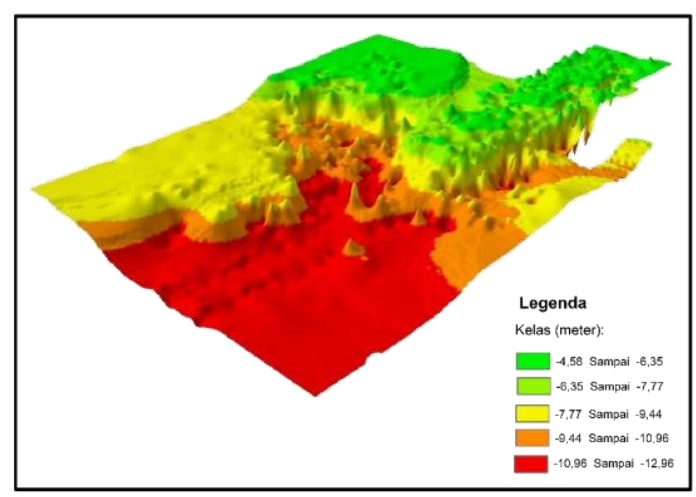

Gambar 9. Peta 3D Surface menggunakan data survei lapangan terkoreksi

\section{A. Konstanta Harmonik}

Tabel 1. Nilai konstanta harmonik pasang surut

\begin{tabular}{cccc}
\hline No & Simbol & Z0 & $\begin{array}{c}\text { Amplitudo } \\
(\mathbf{m})\end{array}$ \\
\hline 0 & Z0 & 0,0001 & 0,0001 \\
1 & M2 & & 0,5977 \\
2 & S2 & & 0,1998 \\
3 & N2 & & 0,1005
\end{tabular}


Identifikasi Kedalaman Perairan (Batimetri) Terhadap Nilai Kedalaman Data Satelit di Perairan Batu Ampar, Batam (Muhammad Zainuddin Lubis)

\begin{tabular}{|c|c|c|c|}
\hline No & Simbol & $\mathbf{Z 0}$ & $\begin{array}{c}\text { Amplitudo } \\
(\mathrm{m})\end{array}$ \\
\hline 4 & K2 & & 0,0317 \\
\hline 5 & K1 & & 0,2849 \\
\hline 6 & O1 & & 0,2463 \\
\hline 7 & P1 & & 0,1119 \\
\hline 8 & M4 & & 0,0001 \\
\hline 9 & MS4 & & 0,0001 \\
\hline
\end{tabular}

Berdasarkan pada Tabel 1 perhitungan konstanta harmonik dengan menggunakan rumus formzahl maka didapatkan nilai $\mathrm{F}$ yaitu sebesar $=0,6660815047$ dari hasil perhitungan di bawah ini yang artinya bahwa pasang surut bertipe pasang surut campuran condong ke harian ganda, dengan perhitungan sebagai berikut;

$$
\begin{aligned}
& F=\frac{A(K 1)+A(O 1)}{A(M 2)+A(S 2)} \\
& F=\frac{0,2849+0,2463}{0,5977+0,1998} \\
& F=0,666
\end{aligned}
$$

Selain mendapatkan nilai formzahl, 9 konstanta utama dapat menentukan nilai water level serta chart datum. Dalam menentukan chart datum sebaiknya mengetahui nilai water level terlebih dahulu. Dalam mendapatkan nilai chart datum ada parameter SO dan ZO. SO adalah permukaan air laut rata-rata dan Z0 adalah muka surutan peta. Untuk mendapatkan nilai Z0 penulis menggunakan definisi dari DISHIDROS, dimana DISHIDROS digunakan sebagai acuan peta laut di Indonesia [9]. Hal ini menunjukkan hasil nilai pasang surut laut yang tidak jauh berbeda dengan dilakukannya penelitian sebelumnya [10]

Tabel 2. Nilai-nilai elevasi water level

\begin{tabular}{cccc}
\hline Simbol & & & $\begin{array}{c}\text { Elev } \\
(\mathbf{m})\end{array}$ \\
\hline HHWL & 2,34728048 & $\approx$ & 2,3 \\
MHWL & 2,004891241 & $\approx$ & 2 \\
MSL & 1,651329059 & $\approx$ & 1,65 \\
MLWL & - & & $-0,25$ \\
LLWL & 0,252747842 & & $-0,59526454$ \\
\hline \multicolumn{2}{l}{ Tabel 3. Hasil perhitungan Zo dan MSL }
\end{tabular}

10

\begin{tabular}{ccc}
\hline Ket & Zo $(\mathbf{m})$ & So $(\mathbf{m})$ \\
\hline Elevasi & 2,6881 & 2,447757877 \\
\hline
\end{tabular}

Tabel 4. Sample nilai koreksi Z pengukuran survei lapangan

\begin{tabular}{|c|c|c|c|c|c|}
\hline \hline OBJECTID & DateTime & $\mathbf{x}$ & $\mathbf{y}$ & $\mathbf{Z 1}$ & Koreksi nilai z \\
\hline \hline 13.000000 & $9 / 20 / 2018$ & 388918.182395 & 129044.896193 & -5.890000 & -9.909444 \\
\hline 14.000000 & $9 / 20 / 2018$ & 388931.645923 & 129033.855577 & -5.800000 & -7.371686 \\
\hline 15.000000 & $9 / 20 / 2018$ & 388942.834892 & 129026.272034 & -5.850000 & -5.850000 \\
\hline 16.000000 & $9 / 20 / 2018$ & 388945.231396 & 129024.992482 & -5.870000 & -5.870000 \\
\hline 17.000000 & $9 / 20 / 2018$ & 388943.589327 & 129023.223311 & -5.810000 & -5.810000 \\
\hline 18.000000 & $9 / 20 / 2018$ & 388943.225622 & 129023.316079 & -5.840000 & -5.840000 \\
\hline 19.000000 & $9 / 20 / 2018$ & 388943.738713 & 129023.714310 & -5.770000 & -5.770000 \\
\hline 20.000000 & $9 / 20 / 2018$ & 388934.083356 & 129043.185576 & -6.000000 & -6.000000 \\
\hline 21.000000 & $9 / 20 / 2018$ & 388932.905436 & 128982.605025 & -5.910000 & -5.910000 \\
\hline 23.000000 & $9 / 20 / 2018$ & 388932.430806 & 128880.457075 & -5.960000 & -5.960000 \\
\hline \hline
\end{tabular}

Nilai reduksi (koreksi) pengukuran didapatkan menggunakan persamaan (1). TWLt yang dipakai pada data ini adalah nilai $\mathrm{Z1}$. Dengan waktu yang dimulai dari tanggal 20-092018 sampai tanggal 21-09-2018 didapatkan nilai $X$ dan $Y$ serta nilai $Z$ yang dimana akan di koreksi lagi sesuai dengan nilai-nilai chart datum yang telah tersedia pada Gambar 10. Grafik koreksi nilai Z Tabel 4. Grafik pada Gambar 10 merupakan grafik scatter dengan tipe poin yang berisi koreksi nilai $z$ nya yang dimulai dari rentang -10 sampai -5 dengan jumlah data 315 .

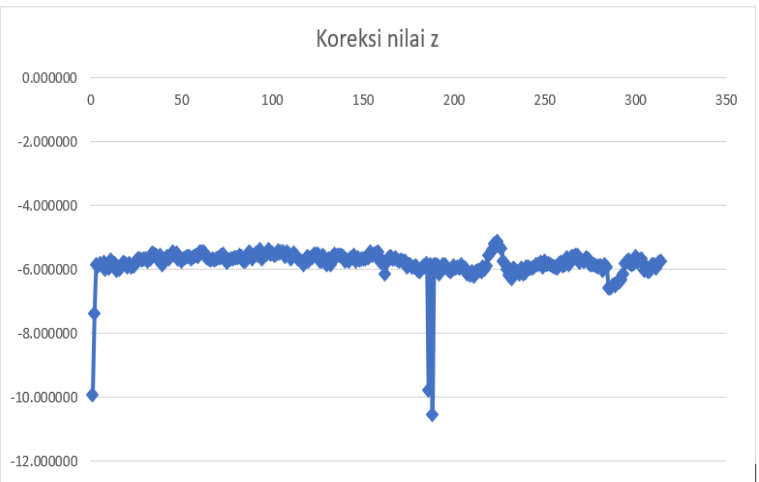

Gambar 10. Grafik koreksi data survei lapangan

Tabel 5. Sample nilai koreksi Z pengukuran survei lapangan

\begin{tabular}{|l|r|c|c|c|r|}
\hline \multicolumn{7}{|c|}{ ANOVA } \\
\hline & \multicolumn{1}{|c|}{$d f$} & \multicolumn{1}{c|}{ SS } & \multicolumn{1}{c|}{ MS } & \multicolumn{1}{|c|}{ S } & \multicolumn{1}{|c|}{ Significance $F$} \\
\hline Regression & 1 & 78.0778241 & 78.0778241 & 1.795721 & 0.181202692 \\
\hline Residual & 313 & 13609.22101 & 43.47993934 & & \\
\hline Total & 314 & 13687.29884 & & & \\
\hline
\end{tabular}


Tabel 6. Nilai Regresi dan Standard Error

\begin{tabular}{|c|c|c|c|c|c|c|c|c|}
\hline & $\begin{array}{c}\text { Coefficie } \\
n t s\end{array}$ & $\begin{array}{c}\text { Standard } \\
\text { Error }\end{array}$ & ${ }_{t \text { Stat }}$ & \begin{tabular}{c|}
$\begin{array}{c}P- \\
\text { value }\end{array}$ \\
\end{tabular} & $\begin{array}{c}\text { Lower } \\
95 \% \\
\end{array}$ & $\begin{array}{c}\text { Upper } \\
95 \%\end{array}$ & \begin{tabular}{l|l} 
Lower \\
$95.0 \%$ \\
\end{tabular} & $\begin{array}{l}\text { Upper } \\
95.0 \% \\
\end{array}$ \\
\hline $\begin{array}{c}\text { Interce } \\
\mathrm{pt}\end{array}$ & $\begin{array}{r}15.73458 \\
676\end{array}$ & $\begin{array}{r}4.478907 \\
407\end{array}$ & $\begin{array}{r}3.513041 \\
314\end{array}$ & $\begin{array}{r}0.0005 \\
08\end{array}$ & $\begin{array}{r}24.5471 \\
597\end{array}$ & $\begin{array}{r}6.922013 \\
87\end{array}$ & $\begin{array}{r}24.5471 \\
597\end{array}$ & $\begin{array}{r}6.922013 \\
87\end{array}$ \\
\hline $\begin{array}{r}\text { Data } \\
\text { surveil }\end{array}$ & & & & & & & & \\
\hline $\begin{array}{c}\text { Lapang } \\
\text { an }\end{array}$ & $\begin{array}{r}1.029975 \\
807 \\
\end{array}$ & $\begin{array}{r}0.768612 \\
844 \\
\end{array}$ & $\begin{array}{r}1.340045 \\
011 \\
\end{array}$ & $\begin{array}{r}0.1812 \\
03 \\
\end{array}$ & $\begin{array}{r}2.54227 \\
693 \\
\end{array}$ & $\begin{array}{r}0.482325 \\
319 \\
\end{array}$ & $\begin{array}{r}2.54227 \\
693 \\
\end{array}$ & $\begin{array}{r}0.482325 \\
319 \\
\end{array}$ \\
\hline
\end{tabular}

Analisis yang mengukur hubungan statistik yang terjadi antara dua variabel atau lebih, biasanya dinyatakan dengan suatu persamaan regresi yang disebut analisis Regresi. Regresi linear merupakan salah satu contoh dari banyaknya jenis Regresi. Regresi Linear memiliki banyak data yang diikuti garis kemana data menunjukkan angka semakin besar, bisa bernilai positif maupun negatif. Hal ini dapat dilihat juga pada Tabel 7 dan Gambar 11.

Tabel 6. Hasil analisa statistik

\begin{tabular}{lr}
\hline \multicolumn{2}{c}{ SUMMARY OUTPUT } \\
\hline \multicolumn{1}{c}{ Regression Statistics } \\
Multiple R & 0,075527477 \\
R Square $\left(\mathrm{R}^{2}\right)$ & 0,0057044 \\
Adjusted R Square & 0,002527736 \\
Standard Error & 6,593932009 \\
Observations & 315 \\
\hline
\end{tabular}

Rumus umum Regresi Linear yaitu $\mathrm{y}=\mathrm{bx}$ $+a$, yang dimana $Y$ dan $X$ merupakan Variabel yang berbeda. Pada data penelitian ini Variabel $Y$ merupakan Variabel terikat yang artinya variabel yang diestimasi nilainya karena pengaruh variabel independent atau Variabel $X$. Dimana nilai Variabel $Y$ pada data ini bersifat Negatif, $y=-$ $1,03 x$ - 15,735. Untuk Variabel $X$ merupakan Variabel bebas yang artinya variabel yang diasumsikan memberikan pengaruh terhadap variabel hasil (terikat). Untuk nilai A dan B merupakan konstanta dimana nilai $A$ dan $B$ ini bisa disubstitusi. Konstanta A (intersep / konstanta) disubstitusi dengan kolom pada Microsoft excel yaitu kolom Z Koreksi Batimetri. Untuk Konstanta B (koefisien regresi / slop) disubstitusi dengan kolom pada Microsoft excel yaitu kolom Z Satelit. Maka grafik akan menampilkan hasil dari grafik Regresi Linear dengan data-data yang sudah dimasukkan yang dapat dilihat pada Gambar 11.

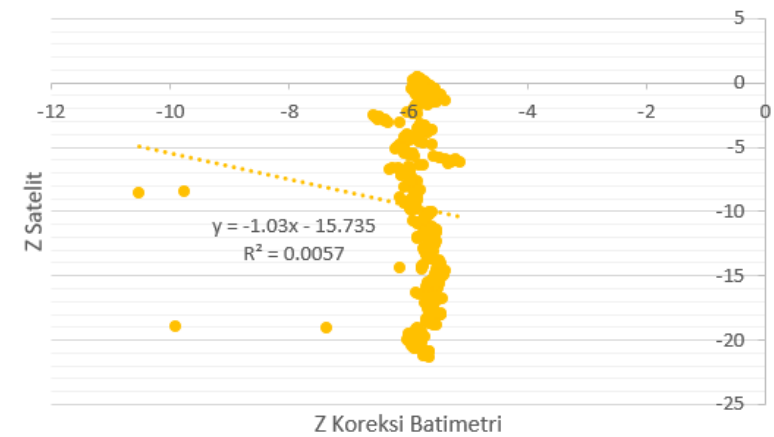

Gambar 11. Grafik regresi linear X(koreksi Batimetri), dan $Y$ (data batimetri satelit)

Dalam hal hasil penelitian ini Standard Errormerupakan nilai standard error dari estimasi variabel terikat (antara $x$ dan $y$ ). Hail ini dilakukan perbandingan nilai yang menghasilkan nilai angka standard error yang sangat tinggi. Hal ini disebabkan adanya data yang sangat berbeda yaitu nilai kedalaman perairan (batimetri) yang berasal dari data satelit. Sehingga dengan analisa ini data satelit dapat dinyatakan berbeda signifikan dengan data pemeruman batimetri yang dilakukan di perairan batu ampar, Batam.

\section{Simpulan}

Hasil pengolahan data pasang surut yang dilakukan di daerah perairan Batu Ampar yaitu memiliki tipe pasang surut campuran condong ke harian ganda. Chart datum Mean Sea Level (MSL) yang diperoleh dari hasil penelitian ini merupakan hasil perhitungan dari data pasut selama 15 hari memberikan hasil yang akurat sebagai nilai koreksi kedalaman perairan (batimetri). Perhitungan uji regresi dan standard error didapatkan yaitu: Standard Error= 6,593932009 dan nilai regresi $=0,0057044$. Hal ini menunjukkan hasil yang sangat memiliki perbedaan yang nyata atau signifikan terhadap kedua variabel ( $\mathrm{X}$ dan $\mathrm{Y})$.

\section{Daftar Pustaka}

[1]. Lubis, M. Z., Anurogo, W., Khoirunnisa, H., Irawan, S., Gustin, O., \& Roziqin, A. "Using Side-Scan Sonar instrument to Characterize and map of seabed identification target in punggur sea of the Riau Islands, Indonesia." Journal of Geoscience, Engineering, Environment, and Technology, vol. 2, pp. 18. 2017.

[2]. Lubis, M. Z., Silaban, R. D., Siboro, A. T., Siahaan, F. A. G., \& Anurogo, W. "Pengaruh Kondisi Oseanografi Terhadap Perubahan 
Iklim Di Daerah Perairan Batu Ampar, Kepulauan Riau." Jurnal Kelautan: Indonesian Journal of Marine Science and Technology, vol 11, pp. 191-199. 2018.

[3]. Hasibuan, R. D., Surbakti, H., \& Sitepu, R. "Analisis Pasang Surut Dengan Menggunakan Metode Least Square Dan Penentuan Periode Ulang Pasang Surut Dengan Metode Gumbel Di Perairan Boom Baru Dan Tanjung Buyut." Doctoral dissertation, Sriwijaya University. 2014.

[4]. Saputra, A. D., Setiyono, H., \& Saputro, A. A. D. "Pemetaan Batimetri dan Sedimen Dasar di Perairan Karangsong, Kabupaten Indramayu, Jawa Barat". Buletin Oseanografi Marina, vol. 5, pp. 38-43. 2016.

[5]. Nugraha, A. L., \& Subiyanto, S. "Analisis Pengukuran Batimetri Dan Pasang Surut Untuk Menentukan Kedalaman Kolam Pelabuhan (Studi Kasus: Pelabuhan Tanjung Perak, Surabaya)." Jurnal Geodesi Undip, vol. 3, pp. 25-36. 2014.

[6]. Permana, H., \& Handayani, L. "Studi awal pola struktur busur muka aceh, Sumatra bagian utara (Indonesia): Penafsiran dan Analisis Peta Batimetri." Jurnal Geologi Kelautan, vol. 8, pp. 105-118. 2016.

[7]. Susanto, E., Arsyad, M., Subaer, S., \& Setyahagi, A. R. "Pemodelan Waktu Tiba Gelombang Tsunami di Wilayah Pesisir Provinsi Sulawesi Barat." In Prosiding Seminar Nasional Fisika PPS Universitas Negeri Makassar, 2020.

[8]. Lubis, M. Z., Pujiyati, S., Prasetyo, B. A., \& Choanji, T. "Bathymetry Mapping Using Underwater Acoustic Technology." Journal of Geoscience, Engineering, Environment, and Technology, vol. 4, pp. 135-138. 2019.

[9]. Brammadi, S., Nugraha, A. L., Sudarsono, B., \& Mudita, I. "Analisis Pengolahan Data Multibeam Echosounder Menggunakan Perangkat Lunak MB-System dan Caris HIPS and SIPS Berdasarkan Standar S-44 IHO 2008." Jurnal Geodesi Undip, vol. 6, pp. 351-360. 2017.

[10]. Sari, D. P., \& Lubis, M. Z. "Pemanfaatan Citra Landsat 8 Untuk Memetakan Persebaran Lamun Di Wilayah Pesisir Pulau Batam." Jurnal Enggano, vol. 2, pp. 38-45. 2017 